\title{
The Correlation between the Level of Doxorubicin-Induced Cardiac Damage and Serum Soluble Fas in an Experimental Rat Model
}

\begin{abstract}
Aim: This study was planned to research the relationship between doxorubicin cardiomyopathy and the soluble Fas (sFas) level. Materials and Methods: Two groups of rats were included in the study. The control group was given physiological saline, while the study group was given doxorubicin. The rats, whose blood samples were taken weekly, were sacrificed and their myocardial tissues were removed. The tissues were examined in terms of morphological changes and surface Fas expression, while the blood samples were examined in terms of sFas level. Results: In the study group, the sFas levels at $2^{\text {nd }}-9^{\text {th }}$ weeks were higher than those found at $1^{\text {st }}$ week before administrating the drug, and the increase at $2^{\text {nd }}-7^{\text {th }}$ weeks was meaningful. In addition, sFas levels were gradually increased each week during $1^{\text {st }}-5^{\text {th }}$ weeks when compared to the values of a previous week, and the increase during the first 4 weeks was meaningful. After the $5^{\text {th }}$ week, the values gradually decreased each week. The mean values of the study group at $1^{\text {st }-8^{\text {th }}}$ weeks were higher than those of the control group, and the increases at $2^{\text {nd }}-8^{\text {th }}$ weeks were meaningful. The severe forms of interfibrillar hemorrhage, vascular dilatation, myocardial necrosis, inflammatory infiltration, and splitting of muscle fibers occurred with $15,15,17.5,20$, and $22.5 \mathrm{mg} / \mathrm{kg}$ dose of medicine, respectively. Conclusions: As the tissue injury increased, the increasing cell-surface Fas expression and sFas plasma level at the acute phase of doxorubicin-related cardiotoxicity decreased. The sFas level determined at acute phase may be helpful in predicting the existing injuries and possible late-term problems.

Keywords: Cardiac, doxorubicin, fas, rat
\end{abstract}

\section{Introduction}

Chronic cardiomyopathy, which develops based on dose, is the most significant adverse effect of doxorubicin, which is one of the most essential medications used in the treatment of childhood cancers. ${ }^{[1]}$ Many studies have been conducted to determine doxorubicin-related myocardial injuries at an earlier phase; however, no noninvasive method with high sensitivity and specificity has been found yet.

The aim of this study was to research the possible relation between the doxorubicin-induced cardiac injury level and soluble Fas (sFas) level. In this vein, by determining the existing cardiac injury level and predicting possible long-term cardiac complications, it has been aimed to perform early-phase dose modification or continue the treatment with alternative medications.

\section{Material and Methods}

\section{Ethical declaration}

The ethical approval of this study was

This is an open access journal, and articles are distributed under the terms of the Creative Commons Attribution-NonCommercial-ShareAlike 4.0 License, which allows others to remix, tweak, and build upon the work non-commercially, as long as appropriate credit is given and the new creations are licensed under the identical terms.

For reprints contact: reprints@medknow.com obtained from the ethical board of experimental animals at the center for experimental research and application at our university medical school (approval number: 2013-083), and all the stages of the research were inspected by the same board.

\section{Animal selection}

In this study, 42 3-month-old Wistar Albino rats, randomly selected in terms of gender, with $300 \mathrm{~g}$ average weight were used.

\section{Study groups and procedure}

Two groups of rats, control group and study group which were administrated medicine, each consisting of 21 rats, were included in the study. The control group was given 2, $5 \mathrm{ml} / \mathrm{kg} /$ week serum physiologic, while the study group was intraperitoneally given $2.5 \mathrm{mg} / \mathrm{kg} / \mathrm{week}$ dose of doxorubicin for 10 weeks. Two hours after this application, blood tail samples were taken from each animal, and $2 \mathrm{mg} / \mathrm{ml}$ of acetaminophen was given through tap water as analgesics. After the animals were anesthetized with xylazine hydrochloride in groups of three at weeks

\footnotetext{
How to cite this article: Kose D, Ozdemir $\mathrm{H}$, Celik ZE, Unlu A, Artac H, Koksal Y. The correlation between the level of doxorubicin-induced cardiac damage and serum soluble Fas in an experimental rat model. Indian J Med Paediatr Oncol 2018;39:473-8.
}

\section{Dogan Kose, Hulya Ozdemir ${ }^{1}$, Zeliha Esin Celik ${ }^{2}$, Ali Unlu ${ }^{3}$, Hasibe Artac ${ }^{1}$, Yavuz Koksal}

Departments of Pediatric Hematology and Oncology, ${ }^{1}$ Pediatric Immunology and Allergy, ${ }^{2}$ Pathology and ${ }^{3}$ Biochemistry, Selcuk University, Faculty of Medicine, Konya, Turkey

Address for correspondence:

Dr. Dogan Kose,

Department of Pediatric

Hematology and Oncology,

Selcuk University, Faculty

of Medicine, 42070,

Selcuklu, Konya, Turkey.

E-mail:drdogankose@

gmail.com

Access this article online

Website: www.ijmpo.org

DOI: 10.4103/ijmpo.ijmpo_82_17

Quick Response Code:

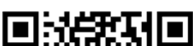

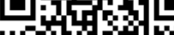

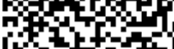

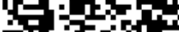

a 
$2,4,6,7,8,9$, and 10, intracardiac blood samples were taken and they were sacrificed, and then the heart muscles were removed. By sacrificing animals at different weeks, it was aimed to determine at what phase the heart muscle injury started, the possible additional tissue changes in animals that were given higher doses of medicine, and the changes in cardiac tissue and sFas level in the peripheric blood due to dose and the correlation between them.

The cardiac tissue samples were divided and placed into two different boxes for pathologic and flow cytometric evaluations.

The tissues, following 10\% formaldehyde and alcohol solution procedures, were changed into paraffin-embedded blocks for the pathologic evaluation. Some of the sections with $4 \mu \mathrm{m}$ thickness taken from these blocks were evaluated under the light microscope by staining with hematoxylin and eosin to determine the injuries and morphological changes (interfibrillar hemorrhage, vascular dilatation, inflammatory cell infiltration, myocardial necrosis, and separation of muscle fibers) in cardiac muscle tissue. The changes determined after the evaluation were scored as: 0 , absent; 1, mild; 2, moderate; and 3, severe. For the rest of the sections, Fas (CD95, APO-1) antibody was administrated using Ventana, Benchmark XT model (Ventana, Tucson, AZ, USA), immunohistochemical staining device, and Ultraview Universal DAB Detection Rat Kit (Roche, Ventana, NY, USA), and Fas expression was evaluated by the light microscope. All sections were taken in cross-section to evaluate all cardiac muscle tissue layers. All the evaluations were performed by the same pathologist who did not know which rats these preparats belong to.

The Fas expression on the surface of the cell was evaluated with 3-laser flow cytometer device (BD FACSARIA III, BD Biosciences, USA) for the flow cytometric assessment after the cardiac tissues were changed into suspension. Complete blood was analyzed with lysis method using a florescent monoclonal antibody marked with PE-CF594 hamster antimouse CD95 (BD Biosciences). Lysing was performed with FACS lysing solution (FACS lyse, Becton Dickinson, San Jose, CA, USA). Cells stained with PE-CF594 hamster IgG2 $\lambda 1$ isotype control were used for negative control. After the data were analyzed with "dot plots" and "histogram plots" on "BD FACS Diva ${ }^{\mathrm{R}}$ " package program (Becton Dickinson, CA, USA), the findings were defined as relative rate and median expression.

For biochemical analysis, the blood serums were centrifuged within $2 \mathrm{~h}$ and kept at $80^{\circ} \mathrm{C}$ until the study date. The serums, melted at room temperature on the day of the study, were used to assess sFas levels using Rayto, Elisa reader device, and Elisa Kit for Rat Factor Related Apoptosis (FAS) (Uscn Life Science Inc. Wuhan, China).

In so doing, it was planned to evaluate the relationship of sFas values, obtained from peripheric blood, both with histopathologically determined cardiac injury and Fas expression and flow cytometrically determined positive Fas cell numbers in cardiac tissue.

\section{Statistical analysis}

The statistical analyses were performed through SPSS software package program (Version 21; Chicago, IL, USA). Since the numerical data used in this study were not appropriate to the normal distribution approach, the data were analyzed with nonparametric Mann-Whitney $U$-test and Wilcoxon signed-rank test. In this study, categoric variables were given as " $n$ " and descriptive statistic was defined as percentage values; for numeric variables, minimum-maximum value and median-standard deviation were used. In all analysis techniques, the level of significance was accepted as 0.05 , and thus, decisions were defined as $95 \%$ confidence interval.

\section{Results}

When the sFas levels of the study group were compared within the group, the average of weeks $2^{\text {nd }}-9^{\text {th }}$ was higher than that of the $1^{\text {st }}$ week before the administration of the medicine, and the higher rate found in the averages of weeks $2^{\text {nd }}-7^{\text {th }}$ was statistically meaningful [Table 1].

Similarly, the averages found in the $3^{\text {rd }}-8^{\text {th }}$ weeks were also higher than that of the $2^{\text {nd }}$ week, and the higher rate in weeks $3^{\text {rd }}-6^{\text {th }}$ was statistically meaningful [Table 2].

Averages of the $4^{\text {th }}-6^{\text {th }}$ weeks were also higher than that of the $3^{\text {rd }}$ week, and the higher rate in $4^{\text {th }}$ week was statistically meaningful [Table 3].

\begin{tabular}{|c|c|c|c|}
\hline Week & $n$ & $1^{\text {st }}$ week $(n=21)$ & $P$ \\
\hline $2^{\text {nd }}$ & 21 & $-48.9 \pm 125.2$ & 0.021 \\
\hline $3^{\text {rd }}$ & 18 & $-107.8 \pm 138.9$ & 0.007 \\
\hline $4^{\text {th }}$ & 18 & $-174.2 \pm 138.8$ & 0.001 \\
\hline $5^{\text {th }}$ & 15 & $-200.0 \pm 124.1$ & 0.001 \\
\hline $6^{\text {th }}$ & 15 & $-139.6 \pm 172.3$ & 0.017 \\
\hline $7^{\text {th }}$ & 12 & $-104.7 \pm 137.8$ & 0.031 \\
\hline $8^{\text {th }}$ & 9 & $-45.8 \pm 187.1$ & 0.441 \\
\hline $9^{\text {th }}$ & 6 & $-4.4 \pm 164.1$ & 0.917 \\
\hline $10^{\text {th }}$ & 3 & $18.7 \pm 156.5$ & - \\
\hline
\end{tabular}

\begin{tabular}{|c|c|c|c|}
\hline Week & $n$ & $2^{\text {nd }}$ week $(n=21)$ & $P$ \\
\hline $3^{\text {rd }}$ & 18 & $-76.6 \pm 142.5$ & 0.025 \\
\hline $4^{\text {th }}$ & 18 & $-143.0 \pm 113.8$ & 0.001 \\
\hline $5^{\text {th }}$ & 15 & $-175.2 \pm 115.3$ & 0.001 \\
\hline $6^{\text {th }}$ & 15 & $-114.8 \pm 127.5$ & 0.005 \\
\hline $7^{\text {th }}$ & 12 & $-79.8 \pm 161.0$ & 0.131 \\
\hline $8^{\text {th }}$ & 9 & $-31.5 \pm 127.5$ & 0.594 \\
\hline $9^{\text {th }}$ & 6 & $34.2 \pm 138.4$ & 0.345 \\
\hline $10^{\text {th }}$ & 3 & $63.2 \pm 31.5$ & 0.109 \\
\hline
\end{tabular}


The sFas values of the study group regularly increased each week between $1^{\text {st }}$ and $5^{\text {th }}$ weeks when compared to the previous week, and the increase within the first 4 weeks was statistically meaningful. However, following the $5^{\text {th }}$ week, sFas values decreased regularly each week, although they were not statistically meaningful. Of these rates, only the one in week 10 was higher than that of week 9 [Table 4].

When the sFas values of the control group were compared within the group, only the mean rate of week 4 was seen to be significantly higher than that of week $6(P=0.006)$.

When the average sFas levels of the groups were compared to each other weekly, it was seen that the rates of $1^{\text {st }}-8^{\text {th }}$ weeks were higher in the study group, and the higher rates in $2^{\text {nd }}-8^{\text {th }}$ weeks were statistically meaningful [Table 5].

When the groups are compared with each other and within themselves in terms of flow cytometrically determined Fas-positive cell numbers, no statistically meaningful difference was detected at any of the weeks.

In the immunohistochemical investigation performed with Fas antibodies, no positive staining was detected neither in control nor in the study group. In control group,

Table 3: The comparison of mean values of $3^{\text {rd }}$ week and the other weeks in the study group

\begin{tabular}{lccc}
\hline Week & $\boldsymbol{n}$ & $\mathbf{3}^{\text {rd }}$ week $(\boldsymbol{n}=\mathbf{1 8})$ & $\boldsymbol{P}$ \\
\hline $4^{\text {th }}$ & 18 & $-66.3 \pm 145.8$ & 0.040 \\
$5^{\text {th }}$ & 15 & $-68.8 \pm 177.4$ & 0.069 \\
$6^{\text {th }}$ & 15 & $-8.4 \pm 175.2$ & 0.649 \\
$7^{\text {th }}$ & 12 & $27.1 \pm 147.8$ & 0.346 \\
$8^{\text {th }}$ & 9 & $42.6 \pm 152.5$ & 0.441 \\
$9^{\text {th }}$ & 6 & $127.9 \pm 145.6$ & 0.074 \\
$10^{\text {th }}$ & 3 & $145.4 \pm 19.9$ & 0.109 \\
\hline
\end{tabular}

while interfibrillar hemorrhage, vascular dilatation, and inflammatory cell infiltration were seen as $62 \%, 90.5 \%$, and $43 \%$ but only slightly, respectively, no myocardial necrosis and separation of muscle fibers were observed. However, in the study group, these pathological findings increased with time, and interfibrillar hemorrhage at $10^{\text {th }}$ week, vascular dilatation between $7^{\text {th }}$ and $10^{\text {th }}$ weeks, inflammatory cell infiltration at $9^{\text {th }}$ and $10^{\text {th }}$ weeks, separation of muscle fibers at $10^{\text {th }}$ week, and myocardial necrosis also at $10^{\text {th }}$ week became severe [Table 6 and Figure 1].

\section{Discussion}

Various studies had been performed previously to detect doxorubicin-related myocardial injuries, including

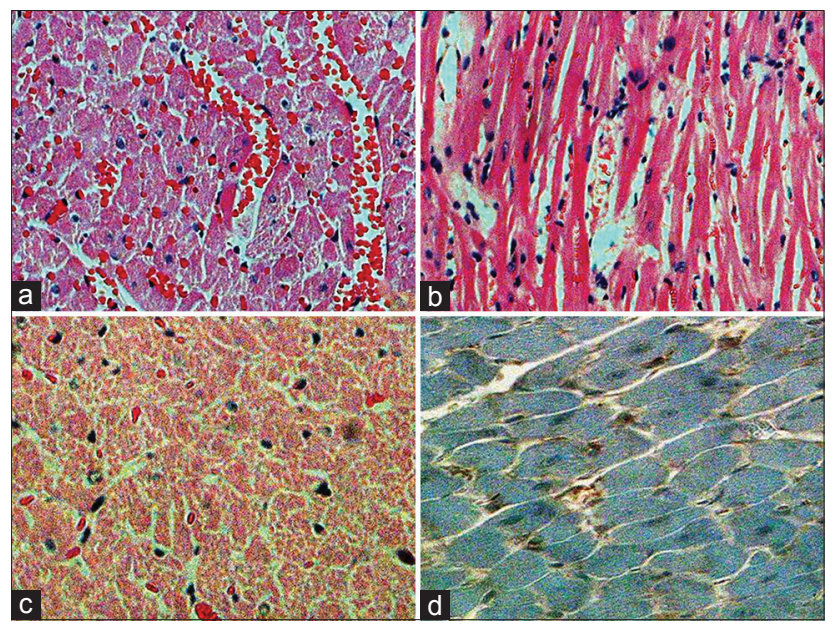

Figure 1: (a) In the drug group, significant interfibrillar hemorrhage and vascular dilatation $(H$ and $E, \times 200)(b)$ in the drug group, significant lymphocyte infiltration ( $\mathrm{H}$ and $\mathrm{E}, \times 200)(\mathrm{c})$ in the drug group, extensive myocardial necrosis (H and E, ×200), (d) immunohistochemical CD95 negativity (CD95, ×400)

\begin{tabular}{|c|c|c|c|c|c|c|c|c|c|}
\hline Week & $1^{\text {st }}(n=21)$ & $2^{\text {nd }}(n=21)$ & $3^{\text {rd }}(n=18)$ & $4^{\text {th }}(n=18)$ & $5^{\text {th }}(n=15)$ & $6^{\text {th }}(n=15)$ & $7^{\text {th }}(n=12)$ & $8^{\text {th }}(n=9)$ & $9^{\text {th }}(n=6)$ \\
\hline $2^{\text {nd }}$ & $-48.9 \pm 125.2$ & & & & & & & & \\
\hline$P$ & 0.021 & & & & & & & & \\
\hline $3^{\text {rd }}$ & & $-76.6 \pm 142.5$ & & & & & & & \\
\hline$P$ & & 0.025 & & & & & & & \\
\hline $4^{\text {th }}$ & & & $-66.3 \pm 145.8$ & & & & & & \\
\hline$P$ & & & 0.040 & & & & & & \\
\hline $5^{\text {th }}$ & & & & $-16.1 \pm 159.3$ & & & & & \\
\hline$P$ & & & & 0.733 & & & & & \\
\hline $6^{\text {th }}$ & & & & & $60.3 \pm 181.1$ & & & & \\
\hline$P$ & & & & & 0.320 & & & & \\
\hline $7^{\text {th }}$ & & & & & & $27.0 \pm 214.5$ & & & \\
\hline$P$ & & & & & & 0.504 & & & \\
\hline $8^{\text {th }}$ & & & & & & & $29.6 \pm 168.6$ & & \\
\hline$P$ & & & & & & & 0.767 & & \\
\hline $9^{\text {th }}$ & & & & & & & & $71.3 \pm 156.8$ & \\
\hline$P$ & & & & & & & & 0.345 & \\
\hline $10^{\text {th }}$ & & & & & & & & & $-16.9 \pm 24.5$ \\
\hline$P$ & & & & & & & & & 0.285 \\
\hline
\end{tabular}


the investigation of serum natriuretic peptide levels, ${ }^{[2]}$ radionuclide screening, monitoring of systolic and diastolic parameters through echocardiography, stress echocardiography performed with exercise and dobutamine, and performing cardiac biopsy. ${ }^{[3]}$ Nevertheless, these studies were regarded insufficient both due to technical challenges and negative physical conditions of oncology patients and the results of such studies.

The doxorubicin-related myocardial injury is irreversible, and its severity is dependent on the dose. ${ }^{[4]}$ The threshold of dose for irreversible myocardial injuries in rats is $27 \mathrm{mg} / \mathrm{m}^{2}$ or $3.8 \mathrm{mg} / \mathrm{kg} .^{[5]}$ This threshold is the closest to that of human beings with $4.6 \mathrm{mg} / \mathrm{kg} .{ }^{[6]}$ While the heart failure risk in human is highly low in doses below

\begin{tabular}{lcccc}
\hline \multicolumn{5}{c}{$\begin{array}{c}\text { Table 5: Comparison of soluble Fas values in both } \\
\text { groups with each other per week }\end{array}$} \\
\hline Week & $\boldsymbol{n}$ & Control group & Drug group & $\boldsymbol{P}$ \\
\hline $1^{\text {st }}$ & 21 & $72.7 \pm 75.4$ & $99.0 \pm 90.9$ & 0.199 \\
$2^{\text {nd }}$ & 21 & $59.9 \pm 43.4$ & $157.5 \pm 79.8$ & $<0.001$ \\
$3^{\text {rd }}$ & 18 & $96.0 \pm 75.5$ & $210.6 \pm 126.6$ & 0.001 \\
$4^{\text {th }}$ & 18 & $87.9 \pm 36.9$ & $276.9 \pm 100.5$ & $<0.001$ \\
$5^{\text {th }}$ & 15 & $100.6 \pm 36.9$ & $298.1 \pm 106.8$ & 0.001 \\
$6^{\text {th }}$ & 15 & $57.8 \pm 46.6$ & $237.7 \pm 111.5$ & $<0.001$ \\
$7^{\text {th }}$ & 12 & $98.1 \pm 69.0$ & $204.1 \pm 144.0$ & 0.031 \\
$8^{\text {th }}$ & 9 & $86.3 \pm 134.5$ & $162.4 \pm 106.6$ & 0.041 \\
$9^{\text {th }}$ & 6 & $113.0 \pm 62.5$ & $89.3 \pm 116.4$ & 0.336 \\
$1^{\text {th }}$ & 3 & $72.0 \pm 36.0$ & $60.3 \pm 42.3$ & 0.513 \\
\hline
\end{tabular}

$450 \mathrm{mg} / \mathrm{m}^{2}(0.1 \%)$, this rate reaches to $7 \%$ with $550 \mathrm{mg} / \mathrm{m}^{2}$ and to $50 \%$ with $1000 \mathrm{mg} / \mathrm{m}^{2} \cdot{ }^{[7]}$ In our study, however, severe interfibrillar hemorrhage and severe vascular dilatation were seen starting week 7 (cumulative dose of medication, $15 \mathrm{mg} / \mathrm{kg}$ ), severe myocardial necrosis was seen starting week 8 (cumulative dose of medication, $17.5 \mathrm{mg} / \mathrm{kg}$ ), severe inflammatory cell infiltration was seen starting week 9 (cumulative dose of medication, $20 \mathrm{mg} / \mathrm{kg}$ ), and severe separation of muscle fibers was seen starting week 10 (cumulative dose of medication, $22.5 \mathrm{mg} / \mathrm{kg}$ ).

In the pathogenesis of doxorubicin-related cardiomyopathy, free oxygen radicals, myocardial adrenergic function disorder, intracellular overload calcium, release of cardiotoxic cytokines, and apoptotic mechanisms were found responsible. ${ }^{[8]}$ While apoptosis is controlled by several proteins such as death receptors, adaptor molecules, Bcl-2, and caspase sequence, caspase sequence is activated through two different ways, one mediated by mitochondria and the other mediated by Fas molecules. ${ }^{[9]}$

Fas is a membrane protein from the tumor necrosis factor family and coded by $10^{\text {th }}$ chromosome. It is expressed in hepatocytes, various tumor cells, lungs, myocardial cells, lymphoid, and epithelial cells ${ }^{[10]}$ and has two isoforms, one as membrane bounded and soluble other. ${ }^{[11]}$ While membrane-bound form is composed of transmembranous and cytoplasmic parts, the soluble form has no transmembranous domain. ${ }^{[12]}$ When agonist antibodies or natural ligands, also known as sFas ligand (sFasL), are

\begin{tabular}{|c|c|c|c|c|c|c|c|c|c|c|c|c|c|}
\hline \multirow[t]{2}{*}{$\begin{array}{l}\text { Rat } \\
\text { number }\end{array}$} & \multirow[t]{2}{*}{ Week } & \multicolumn{2}{|c|}{$\begin{array}{l}\text { Staining with } \\
\text { Fas antibody }\end{array}$} & \multicolumn{2}{|c|}{$\begin{array}{l}\text { Interfibrillar } \\
\text { hemorrhage }\end{array}$} & \multicolumn{2}{|c|}{$\begin{array}{l}\text { Vascular } \\
\text { dilatation }\end{array}$} & \multicolumn{2}{|c|}{$\begin{array}{l}\text { Inflammatory } \\
\text { cell infiltration }\end{array}$} & \multicolumn{2}{|c|}{$\begin{array}{l}\text { Separation of } \\
\text { muscle fibers }\end{array}$} & \multicolumn{2}{|c|}{$\begin{array}{c}\text { Myocardial } \\
\text { necrosis }\end{array}$} \\
\hline & & Control & Drug & Control & Drug & Control & Drug & Control & Drug & Control & Drug & Control & Drug \\
\hline 1 & 2 & 0 & 0 & 1 & 1 & 1 & 1 & 0 & 1 & 0 & 0 & 0 & 0 \\
\hline 2 & & 0 & 0 & 0 & 1 & 0 & 1 & 0 & 1 & 0 & 1 & 0 & 0 \\
\hline 3 & & 0 & 0 & 1 & 1 & 1 & 1 & 1 & 1 & 0 & 1 & 0 & 0 \\
\hline 4 & 4 & 0 & 0 & 1 & 2 & 1 & 2 & 0 & 1 & 0 & 1 & 0 & 0 \\
\hline 5 & & 0 & 0 & 1 & 2 & 1 & 2 & 0 & 1 & 0 & 1 & 0 & 0 \\
\hline 6 & & 0 & 0 & 0 & 1 & 1 & 1 & 1 & 1 & 0 & 1 & 0 & 1 \\
\hline 7 & 6 & 0 & 0 & 1 & 2 & 1 & 2 & 1 & 2 & 0 & 1 & 0 & 2 \\
\hline 8 & & 0 & 0 & 1 & 1 & 1 & 1 & 0 & 2 & 0 & 1 & 0 & 2 \\
\hline 9 & & 0 & 0 & 1 & 2 & 1 & 2 & 0 & 2 & 0 & 1 & 0 & 2 \\
\hline 10 & 7 & 0 & 0 & 1 & 3 & 1 & 3 & 1 & 2 & 0 & 1 & 0 & 2 \\
\hline 11 & & 0 & 0 & 1 & 3 & 1 & 3 & 1 & 2 & 0 & 2 & 0 & 2 \\
\hline 12 & & 0 & 0 & 0 & 2 & 0 & 3 & 0 & 2 & 0 & 2 & 0 & 2 \\
\hline 13 & 8 & 0 & 0 & 1 & 2 & 1 & 3 & 0 & 2 & 0 & 2 & 0 & 3 \\
\hline 14 & & 0 & 0 & 0 & 3 & 1 & 3 & 1 & 2 & 0 & 2 & 0 & 3 \\
\hline 15 & & 0 & 0 & 0 & 3 & 1 & 3 & 0 & 2 & 0 & 2 & 0 & 2 \\
\hline 16 & 9 & 0 & 0 & 0 & 2 & 1 & 3 & 1 & 3 & 0 & 2 & 0 & 3 \\
\hline 17 & & 0 & 0 & 1 & 3 & 1 & 3 & 1 & 3 & 0 & 2 & 0 & 2 \\
\hline 18 & & 0 & 0 & 0 & 3 & 1 & 3 & 0 & 3 & 0 & 2 & 0 & 3 \\
\hline 19 & 10 & 0 & 0 & 1 & 3 & 1 & 3 & 0 & 3 & 0 & 3 & 0 & 3 \\
\hline 20 & & 0 & 0 & 1 & 3 & 1 & 3 & 1 & 3 & 0 & 3 & 0 & 3 \\
\hline 21 & & 0 & 0 & 0 & 3 & 1 & 3 & 0 & 3 & 0 & 3 & 0 & 3 \\
\hline
\end{tabular}

0 - Absent; 1 - Mild; 2 - Moderate; 3 - Severe 
bound, ${ }^{[11]}$ death domain included by cytoplasmic part is bound to a protein called "Fas-Associated Death Domain," and by becoming active caspase system subjects the cell to apoptosis. ${ }^{[13]}$ In addition, Fas expression may also lead to doxorubicin-related cardiotoxicity by inducing inflammation, fibrosis, reactive oxygen species, and hypertrophy. ${ }^{[14]}$

Surface Fas expression on cardiac cells is increased by the effect of doxorubicin. ${ }^{[15]}$ These apoptotic proteins expressed in the membrane may be released into the plasma after separated by proteolytic enzymes, and with this release, the level of soluble forms is increased. ${ }^{[16]}$ In our study, sFas levels between $2^{\text {nd }}$ and $7^{\text {th }}$ weeks were significantly higher in the study group when compared to the levels found at $1^{\text {st }}$ week before the medication. Besides, parallel to the increasing dose of medication, the sFas levels determined in the first four blood samples were also increased significantly when compared to the values of a previous week. However, at the end of the study, there was no meaningful increase in the Fas-positive cell number determined by flow cytometric evaluation. This situation may increase the injury of the tissues based on cumulative medicine dose increased until the end of the study, and therefore, it may also decrease the capacity of cells to express Fas. Since, in our study, sFas levels in the study group gradually decreased each week after the $5^{\text {th }}$ week, and moderate/severe tissue injuries were generally determined at this phase.

Fas ligand is also a protein that is bound to the membrane. Both the form bound to the membrane and the one that can be changed into soluble form after separated by metalloproteinase may induce apoptosis. If regulated correctly, while sFasL-Fas apoptosis mechanisms clear off infected cells and cancerous cells, overworking of this mechanism cause tissue injury. ${ }^{[17]}$ The sFas increased parallel to cell injury in acute phase may prevent inducing apoptosis by binding with natural sFasL in the mainstream. Since studies have shown that higher sFas levels are natural defense mechanisms against antineoplastic treatment. $^{[16]}$ High sFas levels determined during ischemic myocardial injury ${ }^{[18]}$ and chemotherapy ${ }^{[19]}$ are associated with a better prognosis. In addition, the decrease in the number of surface Fas antigens caused by release may decrease the possible injuries by narrowing the area where sFasL can bind to the cell surface and trigger apoptosis; it has been defined that the treatment carried with Fas ligand antibodies improved cardiac functions in doxorubicin-related cardiomyopathy. ${ }^{[14]}$

\section{Conclusion}

Both cell-surface Fas expression and plasma sFas level due to the release of these antigens may increase in the acute phase of doxorubicin-related cardiomyopathy, which increased parallel to the cumulative dose. However, parallel to the increase of the dose and tissue injury, there may be decrease on both eventually. The sFas level determined at acute phase may be beneficial in predicting existing tissue injury and late complications that may appear in the future.

Financial support and sponsorship

Nil.

\section{Conflicts of interest}

There are no conflicts of interest.

\section{References}

1. Von Hoff DD, Layard MW, Basa P, Davis HL Jr, Von Hoff AL, Rozencweig $\mathrm{M}$, et al. Risk factors for doxorubicin-induced congestive heart failure. Ann Intern Med 1979;91:710-7.

2. Nousiainen T, Vanninen E, Jantunen E, Puustinen J, Remes J, Rantala A, et al. Natriuretic peptides during the development of doxorubicin-induced left ventricular diastolic dysfunction. J Intern Med 2002;251:228-34.

3. Weesner KM, Bledsoe M, Chauvenet A, Wofford M. Exercise echocardiography in the detection of anthracycline cardiotoxicity. Cancer 1991;68:435-8.

4. Solcia E, Ballerini L, Bellini O, Magrini U, Bertazzoli C, Tosana G, et al. Cardiomyopathy of doxorubicin in experimental animals, Factors affecting the severity, distribution and evolution of myocardial lesions. Tumori 1981;67:461-72.

5. Iatropoulos MJ. Anthracycline cardiomyopathy: Predictive value of animal models. Cancer Treat Symp 1984;3:3-17.

6. Podestà A, Della Torre P, Pinciroli G, Iatropoulos MJ, Brughera M, Mazué G. Evaluation of 4'-iodo-4'-deoxydoxorubicin-induced cardiotoxicity in two experimental rat models. Toxicol Pathol 1994;22:68-71.

7. Allen A. The cardiotoxicity of chemotherapeutic drugs. Semin Oncol 1992;19:529-42.

8. Nakamura T, Ueda Y, Juan Y, Katsuda S, Takahashi H, Koh E. Fas-mediated apoptosis in adriamycin-induced cardiomyopathy in rats: In vivo study. Circulation 2000;102:572-8.

9. Ashkenazi A, Dixit VM. Death receptors: Signaling and modulation. Science 1998;281:1305-8.

10. Kerr JF, Winterford CM, Harmon BV. Apoptosis. Its significance in cancer and cancer therapy. Cancer 1994;73:2013-26.

11. Jäckel MC, Sellmann L, Dorudian MA, Youssef S, Füzesi L. Prognostic significance of $\mathrm{p} 53 / \mathrm{bcl}-2$ co-expression in patients with laryngeal squamous cell carcinoma. Laryngoscope 2000;110:1339-45.

12. Cheng J, Zhou T, Liu C, Shapiro JP, Brauer MJ, Kiefer MC, et al. Protection from Fas-mediated apoptosis by a soluble form of the Fas molecule. Science 1994;263:1759-62.

13. Yang X, Khosravi-Far R, Chang HY, Baltimore D. Daxx, a novel Fas-binding protein that activates JNK and apoptosis. Cell 1997;89:1067-76.

14. Miyata S, Takemura G, Kosai K, Takahashi T, Esaki M, Li L, et al. Anti-Fas gene therapy prevents doxorubicin-induced acute cardiotoxicity through mechanisms independent of apoptosis. Am J Pathol 2010;176:687-98.

15. Lien YC, Daosukho C, St Clair DK. TNF receptor deficiency reveals a translational control mechanism for adriamycin-induced Fas expression in cardiac tissues. Cytokine 2006;33:226-30.

16. Perik PJ, De Vries EG, Boomsma F, Messerschmidt J, Van Veldhuisen DJ, Sleijfer DT, et al. The relation between soluble apoptotic proteins and subclinical cardiotoxicity in adjuvant-treated breast cancer patients. Anticancer Res 2006;26:3803-11.

17. Yamaoka M, Yamaguchi S, Suzuki T, Okuyama M, Nitobe J, 
Nakamura $\mathrm{N}$, et al. Apoptosis in rat cardiac myocytes induced by Fas ligand: Priming for Fas-mediated apoptosis with doxorubicin. J Mol Cell Cardiol 2000;32:881-9.

18. Niu J, Azfer A, Deucher MF, Goldschmidt-Clermont PJ, Kolattukudy PE. Targeted cardiac expression of soluble Fas prevents the development of heart failure in mice with cardiac-specific expression of MCP-1. J Mol Cell Cardiol 2006;40:810-20.

19. Pichon $M F$, Labroquère $M$, Rezaï $K$, Lokiec $F$. Variations of soluble fas and cytokeratin 18-Asp 396 neo-epitope in different cancers during chemotherapy. Anticancer Res 2006;26:2387-92. 